\title{
Penyutradaraan Teater Bangsawan Dengan Naskah Melayu Peterakna Episode Peri Bunian Karya G.P. Ade Dharmawi
}

\author{
Asri Nofriani ${ }^{1}$ \\ Jurusan Teater, Fakultas Seni Pertunjukan, Institut Seni Indonesia Yogyakarta
}

\begin{abstract}
ABSTRAK
Tujuan penyutradaraan ini adalah menghadirkan unsur-unsur atau elemen-elemen pertunjukan Teater Bangsawan Muda dan Teater Bangsawan Tua sehingga tercipta pertunjukan Teater Bangsawan masa kini. Sejarah dan perkembangan teater bangsawan di Riau memiliki hubungan yang erat dengan teater di semenanjung Malaya. Para peneliti mengkategorikan drama Melayu Bangsawan sebagai drama tradisional. Tulisan berikut membahas drama Peterakna episode Peri Bunian karya GP Ade Dharmawi. Karya yang penulis buat ini menggunakan idiom pola teater bangsawan. Peterakna adalah takhta kerajaan Melayu kuno. Peri Bunian merupakan episode yang menggabungkan dua alam manusia, natural dan supranatural Orang Bunian.
\end{abstract}

Kata kunci: Teater bangsawan, peterakna, orang bunian, teater Riau

\section{ABSTRACT}

The Directing of Bangsawan Theater Using Malay Script Peterakna Episode Peri Bunian Created By G.P. Ade Dharmawi. The aim of this directing is presenting the performance elements of young Bangsawan Theater and old Bangsawan Theater so that the performance of modern Bangsawan Theater can be created. The researchers have categorized Malay drama Bangsawan Theatre as a traditional drama. This article discusses about the show of Peterakna, Episode Peri Bunian created by G.P. Ade Dharmawi which has adopted and used the idiomatic pattern of Bangsawan Theater. Peterakna is the throne of the ancient Malay kingdom. In addition, Peri Bunian is an episode that combines two men's world, the natural and supranatural of Bunian people.

Key words: Teater bangsawan, Peterakna, Peri Bunian, Riau theatre.

\section{Pendahuluan}

Keberadaan seni sebagai salah satu hasil budidaya manusia merupakan realitas kehidupan yang telah dikembangkan oleh umat manusia yang sama tuanya oleh umur manusia itu sendiri. Ketika sektor budaya tampil dengan gaya yang kasar, maka seni hadir dengan kelembutan. Berangkat dari dasar kepribadian yang merupakan seni teater tradisional, akan menguraikan bentuk seni tradisi daerah Riau yakni Teater Bangsawan. Sebagaimana dengan pertunjukan Teater Mendu, Teater Bangsawan mempunyai kesamaan dalam petunjukannya yakni memakai tarian dan nyanyian. Menurut Macgowan dan Melnitz (Akwan, 1984: 43) tarian adalah produk sampingan dari imitasi dan adalah seni pertama dari teater tradisional. Tarian dipersembahkan untuk menyambut bangsa Bunian ke alam nyata atau duniawi. Dalam hal ini, tarian tersebut merupakan tarian khusus bangsa Bunian.
Istilah Bangsawan ini apabila diaplikasikan kepada bentuk seni drama akan membawa arti yang istimewa. Bukan saja mendudukan kumpulan-kumpulan seni drama/teater kepada peringkat yang tinggi pada suatu masa tetapi juga menentukan penerimaan masyarakat sebagai bentuk seni drama yang menjadi kesukaan setiap golongan masyarakat. Para pengkaji dan peneliti drama Melayu mengkategorikan Teater Bangsawan ke dalam drama tradisional. James R. Brandon menyatakan ciri khas Teater Bangsawan umumnya mengemukakan kisah-kisah raja/ kerajaan, tanpa naskah tertulis, bersifat stalistik, improvisatif, visualitatif. Dialog campur-aduk bahasa harian, sastra, nyanyian dan diselangseling dengan tarian. Pementasan dimulai dengan upacara jampi serapah dan percaya bahwa kekuatan gaib turut mengikuti pertunjukan.

Sejarah dan perkembangan Teater Bangsawan Melayu di Riau mempunyai hubungan dengan

1 Alamat korespondensi: Prodi Teater ISI Yogyakarta. Jalan Parangtritis Km. 6,5 Sewon, Yogyakarta. Telepon 0274-375380, e-mail: asri_emo@yahoo.com 
sejarah dan perkembangan Teater Bangsawan di Semenanjung Tanah Melayu. Perkembangan awal teater Bangsawan di Tanah Semenanjung dan Temasik (Singapura) dimulai sejak tahun 1900-an dengan dikembangkannya berbagai kumpulan Teater Bangsawan serta dilaksanakannya berbagai persembahan teater Bangsawan. Pada masa dahulu, penduduk Riau bebas bolak-balik ke berbagai wilayah di Semenanjung Melayu dan Temasik. Selain karena belum adanya aturan yang membatasi wilayah Negara seperti sekarang, pada masa dahulu kerajaan-kerajaan yang ada di Riau mempunyai hubungan kekerabatan dengan kerajaan yang ada di Tanah Semenanjung dan Temasik.

Berbagai kunjungan yang dilakukan Orang Riau ke Tanah Semenanjung dan Temasik umumnya berasal dari kalangan bangsawan suatu Kerajaan atau masyarakat kelas ekonomi menengah ke atas, dalam kunjungan tersebut mereka sering menonton berbagai persembahan Teater Bangsawan. Dari apa yang mereka lihat dan dengar, kemudian muncul keinginan untuk mengembangkan seni pertunjukan teater Bangsawan di daerah asal mereka. Dorongan ini semakin kuat karena dilatar belakangi oleh kesamaan agama; kesamaan bahasa; persamaan adat istiadat; kesamaan seni budaya; dan sebagai media hiburan serta komunikasi.

Perpaduan serasi antara seni, etika, dan agama merupakan ciri khas seni budaya melayu yang senantiasa berpegang pada tatanan :"Indah menurut Estetika, Baik menurut Etika dan Benar menurut Agama”.

Dalam mencari identitas seni budaya, maka seniman, pemikir seni, dan pekerja seni telah memegang teraju dalam aktifitas cultural yang tidak hanya meneruskan seni budaya tradisional, tetapi juga menginterpretasikan sumber-sumber kultural berdasarkan pandangan dan perspektif baru. Kreatifitas kultural mencakup produksi dalam bidang kesenian. (Kartodirdjo, 1987:4)

Di Indonesia ada teater yang berbentuk teater tradisional dan teater yang berbentuk modern. Perpaduan serasi dari berbagai unsur seni diantara keduanya secara dominan tampak nyata dalam seni teater tradisional.

Teater tradisional tergolong kepada kesenian yang bersumber dari kebiasaan yang hidup dan diwarisi secara turun-temurun di dalam masyarakat, serta dirasakan sebagai milik suatu lingkungan masyarakat.Pengolahannya sangat memperhatikan citarasa masyarakat pendukungnya; meliputi tradisi, pandangan hidup atau falsafah, rasa, etik, dan estetik. (Masran, 2000:5)

Manusia yang berada di depan dan mengedepankan diri untuk melakukan perbaikan itu bernama sutradara. Ibarat dalam sebuah peperangan sutradara seperti jendral yang paling terdepan menguasai wilayah peperangan dibandingkan prajuritnya. Dalam bidang teater secara umum maupun teater Bangsawan, sutradara bertanggung jawab menyatukan seluruh kekuatan dari berbagai elemen teater. Seorang sutradara harus mempunyai argumen/alasan yang kuat dan jelas ketika menyampaikan konsep-konsep garapannya.

Naskah Peterakna, Episode Peri Bunian karya G.P. Ade Dharmawi pertunjukan fiksi yang terinspirasi dari peristiwa sejarah dicipta dengan konstruksi teater tradisional Melayu dengan dasar pengolahan naskah mengikuti pola dan bentuk hikayat. Peterakna berarti singgasana kerajaan yang merupakan bahasa Melayu dahulu kala. Episode Peri Bunian merupakan episode yang menggabungkan dua alam, yaitu alam manusia dan alam gaib tempat hunian Bangsa Bunian. Cerita di dalam naskah Peterakna, Episode Peri Bunian karya G.P. Ade Dharmawi bermuatan mistis karena menceritakan kisah cinta Sultan Mahmud Syah II dengan Dewi Menohra puteri Raja Gorda Bianglala dari Kerajaan Bunian.

Kisah percintaan Sultan yang telah dikhianati oleh Maimunah ketika mendapati sedang berselingkuh dengan Megat Seri Rama menjadikan Sultan sebagai sosok pendiam dan tertutup. Di dalam persemediannya akhirnya Sultan menemukan sosok Dewi yang dapat mengisi kekosongan hatinya, yakni Dewi Menohra. Jika dikontekskan dengan kehidupan masa sekarang, bersekutu dengan alam gaib merupakan perbuatan negatif yang tidak harus dilakukan oleh manusia. Pada kodratnya, kehidupan manusia telah diatur oleh Yang Maha Kuasa dan sebagai manusia wajib untuk mensyukuri segala nikmat kehidupan yang telah Ia berikan. Perbuatan negatif atau tindakan tidak baik akan berakibatkan tidak baik pula terhadap manusia itu sendiri. Seperti yang dikisahkan oleh 


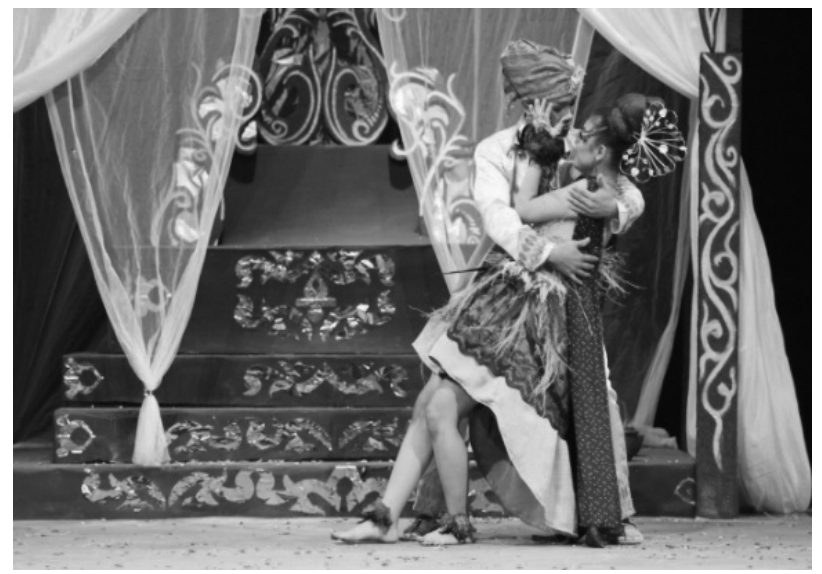

Kisah cinta Sultan Mahmud Syah II dengan Dewi Menohra puteri Raja Gorda Bianglala dari Kerajaan Bunian (Foto: Sigit Setya)

Sultan karena persekutuannya terhadap alam gaib yakni bermain cinta dengan Dewi Menohra maka ia harus mengalami kekecewaan karena tidak tercapainya hasrat cinta terhadap Dewi Menohra.]

\section{Riwayat Pengarang}

Ahmad Darmawi yang dikenal secara formal dalam berbagai biodata resmi, ternyata mempunyai nama lengkap dan gelar keluarga: Gusti Prabu Tanglung Jaeng Pananggak Sungai Tabuk Mas Curai Bintang Karaminan Madu-i Rahmah Ahmad Darmawi Rahman Syukur Ridha alTsaqafiy. Di luar lingkungan kampus; beliau dikenal dengan nama pena (nome de plum/ism al-qalm): G.P. Ade Dharmawi. Sedangkan sapaan akrab atau panggilan namanya cukup beragam, antara lain: Ade/Ahmad/Amat/Dar/Mawi/Awi.

Ade lahir di Sungai Batang - INHIL/4 Juni 1966, anak pertama dari Abdul Murad bin Abdul Rahman (Al-marhum) dan Arbiyah binti $\mathrm{H}$. Syukur (al-Marhumah) dari sepuluh bersaudara. Setelah menyelesaikan pendidikan MI, Mts dan MA Yayasan Pendidikan Islam (YPI) di kampung halamannya Kuala Enok-Tanah Merah, kemudian melanjutkan kuliah di IAIN SUSQA Pekanbaru pada tahun 1985 dan berhasil memperoleh Beasiswa SUPERSEMAR sekaligus menyelesaikan program S.1 pada Fakultas Ushuluddin.

Setelah menamatkan program S1, Ade menikah dengan Dra. Hanifah Aidil Fitri (peraih IPK tertinggi Mahasiswa Konversi Fakultas Ushuluddin) kemudian Ade mengabdikan diri sebagai Tenaga Edukatif.Walaupun telah berkeluarga dan menjadi Dosen, Ade tetap aktif dalam berbagai organisasi dalam dan luar kampus. Tahun 1998, Ade melanjutkan kuliah S.2 pada PPS IAIN SUSQA. Mendapat Beasiswa dan lulus pada tahun 2000 memperoleh IPK tertinggi dengan prediket Cumlaude. Pada tahun yang sama Ade sempat mendaftar pada ATMA - UKM Malaysia (namun tidak berlanjut karena harus mengalihkan biaya untuk keperluan pendidikan dua anaknya ke Ma’had al-Zaytun Indramayu).

Sebagai pendiri sekaligus pembina sanggar Latah Tuah UIN SUSKA Riau, Ade berhasil membawa sanggar ini melanglang keberbagai wilayah nusantara serta menancapkan namanya dalam berbagai event dan berbagai penghargaan tingkat lokal dan nasional. Lima tahun berturut sebagai nominator Organisasi/Lembaga seni budaya pilihan Yayasan Sagang. Puncaknya, pada tahun 2006 Sanggar Latah Tuah terpilih sebagai penerima Anugrah Organisasi/Lembaga seni budaya pilihan Yayasan Sagang.

Ketika di Ibtidaiyah Ade sudah mulai menapaki jalur seni peran, hal ini berawal dari hobinya menonton film sejak kecil. Dari berbagai pengalaman dan kemampuan yang telah dihimpun selama perjalanan kreativitas seni serta setelah bergabung, mendirikan dan membina sanggar, akhirnya menghantarkan Ade pada satu titik kulminasi dunia perteateran Riau.

Selain sebagai seorang Aktor yang berkarakter, Ade juga dikenal sebagai Sutradara Bertangan Dingin. Berbagai naskah sudah disutradarainya, baik karyanya sendiri maupun karya orang lain, diantaranya: Sri Serawak; Cik Puan; Panglima Batang Betarah; Panglima Layar; Lancang Kuning; Hang Tuah; Jebat Mendurhaka; Roh; Terbit Bulan Tenggelam Bulan; Menjaring Angin; Menyuluh Siang; Abu; Malam ke-100; Baginda Raja; Burung Tiung Sri Gading; Orang-orang Bawah Tanah dan Kebebasan Abadi.

\section{Sinopsis Cerita}

Dalam riwayat, terdapat beberapa sultan yang terkenal dalam catatan sejarah Melayu. Salah satunya adalah Sultan Mahmud Syah II maharaja kerajaan Johor yang memerintah pada tahun 1685 sampai 1699 M. Banyak peristiwa aneh yang melingkupi dan menghiasi perjalanan hidupnya. Sebagai sultan yang sudah tidak lagi muda belia, banyak pihak yang coba mencari jawaban apa yang menyebabkan Sultan Mahmud Syah tidak 
menikahi seorang perempuan untuk dijadikan sebagai permaisuri pendamping dirinya selaku raja pada kerajaan Johor.

Ada yang menduga bahwa baginda Pondan (shemale/bencong), ada yang mengaitkannya dengan tidak terwujudnya cinta baginda kepada Maimunah yang akhirnya menjadi isteri Megat Seri Rama, ada pula yang menyimpulkan bahwa baginda sudah merasa bahagia karena telah menjalin hubungan cinta mistis dengan Dewi Menohra dari bangsa Bunian yang telah baginda temukan dalam persemediannya setiap malam. Baginda sering melakukan persemedian setelah cintanya terkhianati oleh Maimunah.Dari situlah baginda jatuh hati terhadap Dewi Menohra.

Hubungan sumbang ini sempat ditolak oleh ayahanda Dewi Menohra yakni Raja Gorda Bianglala karena mereka bukan dari satu bangsa yang sama. Tetapi karena kekuatan hati Dewi Menohra terhadap baginda karena ingin menolong kerajaan dari tangan yang tidak sepantasnya memiliki kerajaan, Dewi Menohra meminta izin dengan segala resiko yang telah ia terima. Akhirnya, Raja Gorda Bianglala memberikan izin kepada anak yang sangat ia sayangi itu.

Sebagai Raja di kerajaan Johor, Sultan harus mempunyai keturunan untuk mewarisi kerajaan Johor pada saat itu. Tetapi melalui Dewi Menohra kekasihnya, ia tidak bisa memberikan keturunan sebagai penerus kerajaan. Akhirnya percintaan Sultan dan Dewi Menohra selesai dengan kehadiran Cik Apong yang akan memberikan keturunan dari Sultan untuk mewarisi kerajaan. Cik Apong adalah putri Istana dan masih keturunan dari Raja terdahulu. Tetapi sepeninggal Dewi Menohra, ia telah berjanji kepada Sultan untuk mengawasi anak keturunan Sultan selanjutnya.

Bagaimana hubungan cinta yang tidak lazim tersebut? Apa dampak positif dan negatifnya bagi Sultan Mahmud Syah serta bagi keberadaan kerajaan johor? Apa yang dirahasiakan oleh Sultan seputar percintaannya sehingga banyak peristiwa yang tidak dapat dicatat oleh sejarah? Naskah Peterakna dalam episode Peri Bunian coba mencari dalil yang menjustifikasi keabsahan Raja Kecil sebagai keturunan Sultan Mahmud Syah II (Sultan Mangkat Dijulang) melalui terawang imajinatif fiktif berdasarkan fakta historikal. Raja Kecil yang lahir dari rahim Cik Apong melalui proses percintaan sumbang Sultan dengan Dewi
Menohra telah menjawab bahwa penerus kerajaan Johor setelah Sultan Mahmud Syah II adalah Raja Kecil supaya dapat menghalangi niat para pelaku yang ingin memanfaatkan keadaan Istana tanpa penerus kerajaan.

Dalam hal ini dapat dilihat bahwa pembenihan Raja Kecil oleh Sultan terhadap Cik Apong adanya peristiwa politik yang dilakukan oleh hubungan sumbangnya terhadap Dewi Menohra. Imajinasi Sultan yang menghadirkan sosok Dewi Bunian hanya pelampiasan patah hatinya kepada Maimunah.Tetapi dibalik peristiwa itu terjadi peristiwa politik yang mengharuskan Sultan untuk mempunyai seorang keturunan sebagai penerus Kerajaan.

\section{Perancangan}

Naskah tidak akan menjadi sebuah karya jika tidak dipentaskan dalam bentuk pertunjukan. Sebelum mementaskan sebuah karya seni terlebih dahulu sutradara menganalisis naskah yang kemudian masuk dalam proses latihan. Selanjutnya merupakan tahap yang memberikan ruang kepada sutradara untuk mengeksplor gagasangagasan atau ide tentang konsep pementasan dan gaya pemanggungan. Hal ini dilakukan setelah sutradara selesai menganalisis lakon yang akan dipentaskan agar mendapatkan gambaran terciptanya suatu pementasan. Namun konsep dan bentuk kemungkinan akan berubah berkat masukan dan kerjasama pendukung pertunjukan.

Selain itu, pemilihan pendukung artisitik dan produksi dapat dilakukan oleh sutradara dengan cara terbuka bagi orang-orang yang ingin mengikuti proses dalam sebuah pementasan karya teater. Sedangkan pemilihan pelaku aktor dan aktris serta penari harus dilakukan dengan cara memilih orang-orang yang berbakat dalam menyanyi, menari dan akting sesuai dengan keinginan sutradara untuk mengambil atau membaca kembali sejarah pola Teater Bangsawan.

Hal pertama yang dilakukan oleh sutradara adalah melihat dan menafsirkan lakon terhadap naskah untuk medapatkan bentuk lakon yang dapat menimbulkan efek cerita yang disampaikan oleh pembaca lakon.Dalam naskah Peterakna, Episode Peri Bunian karya G.P. Ade Dharmawi terdapat lakon yang menyampaikam cerita lucu dan frontal dengan bahasa keseharian rakyat Melayu. Dialog lucu ini sering diucapkan oleh 
Bujang Selamat dan Mak Inang selaku abdi kerajaan Johor yang penyampaiannya dengan bahasa Melayu sehari-hari. Sasaran mereka dalam berdialog lucu biasanya saling mengejek antara satu dengan yang lain karena diantara mereka berdua terikat perasaan jatuh cinta tetapi saling tidak mau untuk mengakuinya.

Selain itu penyutradaraan juga harus memperhatikan gaya pemanggungan yang merupakan ciri khas dari suatu garapan pementasan. Naskah Peterakna, Episode Peri Bunian karya G.P. Ade Dharmawi yang merupakan salah satu bentuk teater Bangsawan yang masih kental dengan nilainilai tradisi budaya Melayu, tetapi akan digarap kembali oleh sutradara dengan hanya mengambil idiom yang terkandung dari teater Bangsawan. Bentuk dan ciri-ciri teater Bangsawan yang telah dipaparkan sebelumnya akan dijadikan panutan dalam penggarapan ini.

Dengan memahami pola Teater Bangsawan tersebut, sutradara mengambil ciri atau pola Teater Bangsawan, yakni pada awal adegan menghadirkan tempo lambat dimana terlihat aktivitas-aktivitas para abdi kerajaan dalam Istana sedang wira-wiri melakukan pekerjaan. Ditengah-tengah aktivitas tersebut muncul para tokoh memperkenalkan diri dan peran yang akan dimainkan dalam pementasan tersebut. Hal ini diambil dari salah satu ciri khas pola Teater Bangsawan yang menghadirkan tablo. Selain itu, dialog antara lawan tokoh banyak yang dilontarkan terhadap penonton dalam bentuk percakapan.

Tata pentas naskah Peterakna, Episode Peri Bunian karya G.P. Ade Dharmawi tetap mengambil pola atau ciri khas teater Bangsawan, seperti keberadaan set dekor dan properti adalah penunjang bagi terciptanya tempat, waktu, dan keadaan atau suasana.Oleh karena dalam persembahan Teater Bangsawan baik Bangsawan Tua maupun Bangsawan Muda terikat pada panggung proscenium yakni panggung yang dapat dilihat oleh penonton dari satu sisi, yaitu dari depan saja. Bentuk panggung prosenium berbentuk kotak, dengan sisi kanan, kiri dan belakang panggung dijadikan jalan keluar-masuk pemain.
Bentuk prosenium akan memudahkan sudut pandang penonton karena dapat dilihat dari satu sisi dan tata pentas yang di belakang panggung tidak akan terlihat penonton. Dalam membuat tata pentas di panggung harus memperhatikan proporsi atau perimbangan dengan luas panggung atau jumlah pemain serta apa alasan yang mendasarinya. Tata pentas dalam naskah Peterakna, Episode Peri Bunian karya G.P. Ade Dharmawi yang tampak jelas dari bagian depan adalah gambar panggung Istana kerajaan Johor. Properti yang digunakan merupakan isi Istana, seperti tahta kerajaan atau peterakna, pusaka kerajaan dalam bentuk senjata atau payung kebesaran lainnya.

Penataan busana dalam pertunjukan Teater Bangsawan Busana yang dipakai pelakon dalam pementasan teater harus sesuai dengan pemilihan karakter yang akan diperankan. Tata busana harus didesain terlebih dahulu yang disesuaikan dengan karakter, ruang dan waktu serta keadaan jalan cerita.Dalam lakon Peterakna, Episode Peri Bunian karya G.P. Ade Dharmawi, Sultan Mahmud Syah II didominasi oleh kuning sebagai warna kebesaran raja.

Musik dan Tari dalam pertunjukan Teater Bangsawan Peterakna, Episode Peri Bunian karya G.P. Ade Dharmawi membawa pengaruh yang besar terhadap pertunjukan. Musik yang dihadirkan adalah musik tradisi melayu dengan segala peralatan musik khas Melayu, sedangkan tarian diambil dari tarian Zapin yang merupakan ciri khas tarian Melayu.

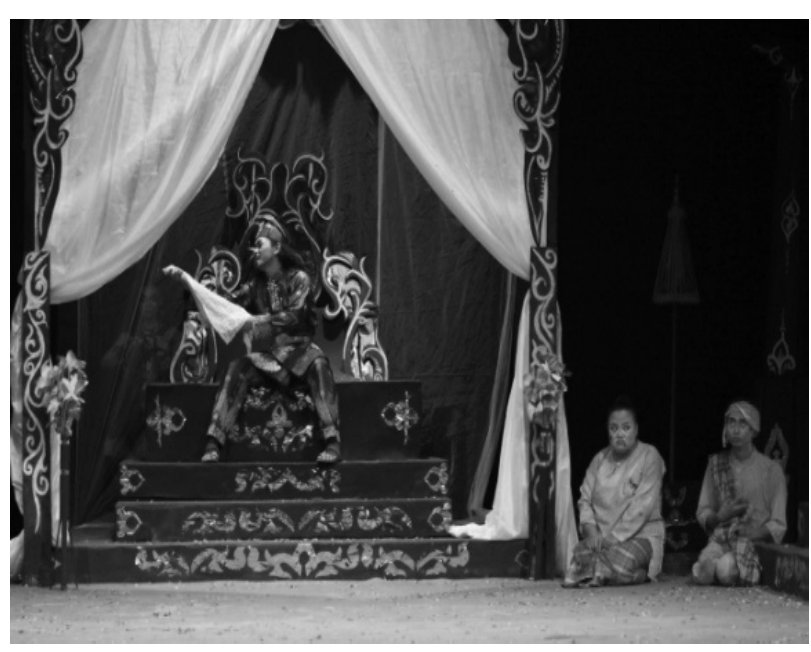

Peterakna Sultan Mahmud II (Foto: Sigit Setya) 


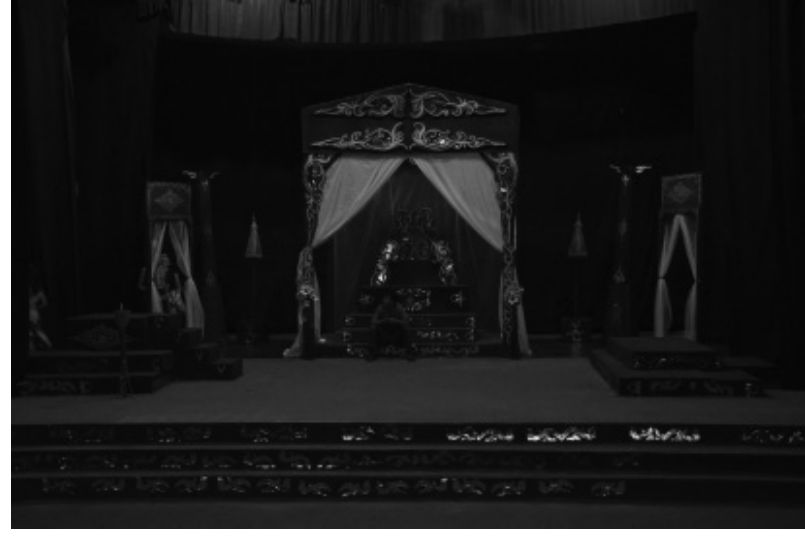

Peterakna Sultan Mahmud II (Foto: Ikhsan Bastian)

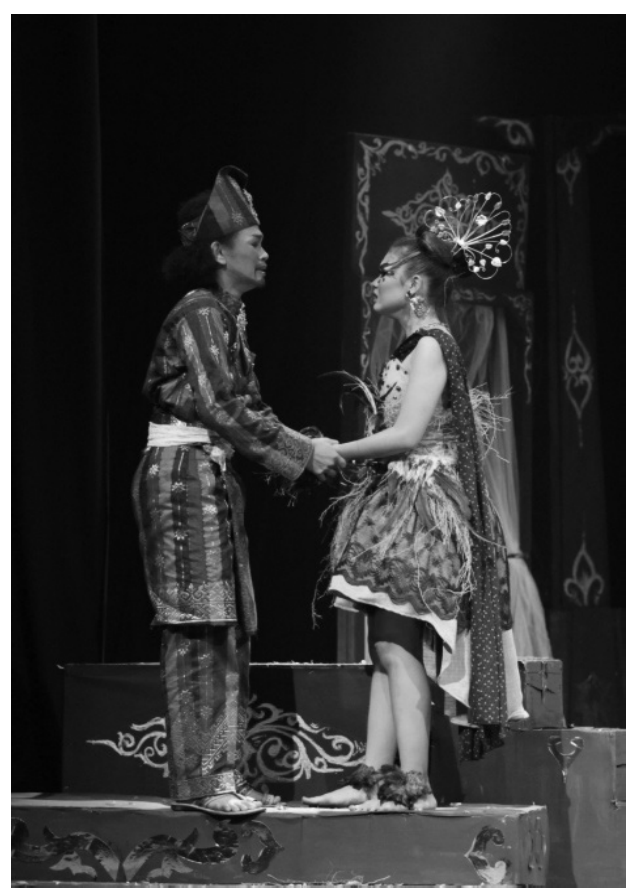

Perpisahan Dewi Manohra dan Sultan Mahmud Syah II (Foto: Sigit Setya)

\section{Pemilihan Pemain}

Pemain merupakan salah satu pembentuk lakon dalam sebuah pementasan teater. Dalam memilih pemain sutradara menggunakan cara penyampaian terbuka kepada pelaku teater yang dikenalnya. Selain pelaku teater tersebut seseorang yang dikenalnya juga haruslah pemain yang memahami bahasa Melayu karena naskah Peterakna merupakan naskah tradisi Melayu. Cukup sulit bagi sutradara mencari pelaku teater dengan dasar merupakan orang Melayu, tetapi sutradara membuka kepada selain orang Melayu untuk mempercayai pelaku tokoh dalam naskah Peterakna dengan komitmen bahwa orang tersebut mau belajar. Pertimbangan lainnya yaitu pemain harus mempunyai keterampilam akting, menyanyi, dan menari. Porsi kemampuan akting dan menari seorang pemain diseleksi secara seimbang.

Berikut adalah calon pemain yang mendekati karakter yang diinginkan sutradara baik secara fisik, vokal, dan karakter aktingnya.Tokoh Sultan Mahmud Syah merupakan Raja Johor yang mempunyai suara bagus dan tubuh yang tegap seperti seorang Raja. Sutradara melihat dari beberapa pelaku teater, banyak yang berakting bagus tetapi tidak disertai dengan kemampuan vokal bernyanyi yang bagus. Tokoh Bujang Selamat dipilih pemain yang gesit, lucu, kurus, dengan lafal bahasa Melayu yang bagus.Tidak hanya pandai berbahasa Melayu tetapi mengetahui dialek dan logat Melayu secara utuh.Tokoh Mak Inang dipilih pemain yang bertubuh gendut dan cerewet. Sama dengan tokoh Bujang bahwa Mak Inang juga harus mempunyai lafal serta dialek bahasa Melayu yang bagus. Tokoh Dewi Menohra dipilih pemain yang mempunyai wajah cantik dan berkulit putih serta pandai menari, sedangkan tokoh Gorda Bianglala dipilih pemain yang mempunyai kemampuan keaktoran yang bagus dan bermuka seram.

Setelah menemukan pelaku teater yang telah dipercaya memainkan tokoh dalam lakon Peterakna, Episode Peri Bunian karya G.P. Ade Dharmawi, sutradara melakukan pertemuan pertama terhadap para pemain. Hal ini dilakukan untuk pembagian tokoh peran berdasarkan kemampuan dan kemauan aktor memainkan peran tersebut serta memberikan beberapa referensi untuk mendalami logat atau dialek Melayu.

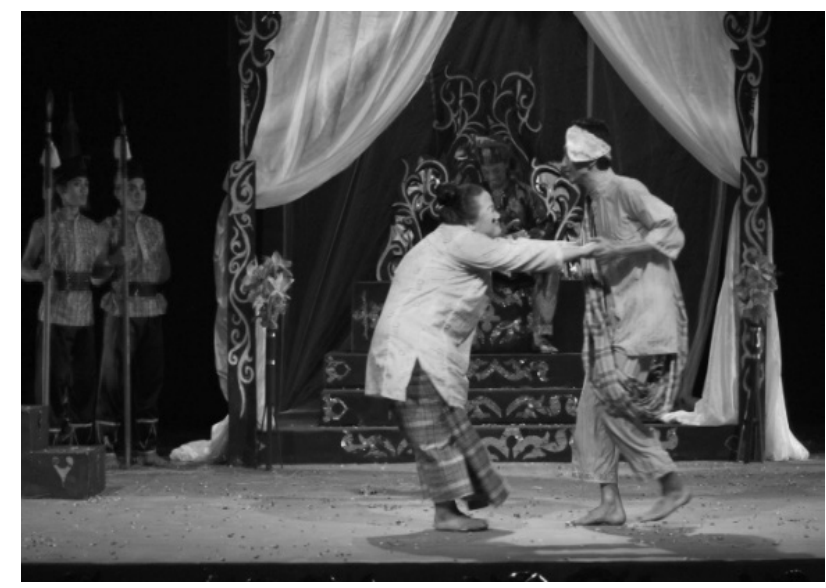

Bujang dan Mak Inang (Foto: Sigit Setya) 


\section{Pemilihan Tim Produksi}

Sutradara menentukan tim produksi dengan cara menentukan seorang untuk menjabat sebagai pimpinan produksi dengan cara memilih atau siapa yang bersedia menyatakan dirinya sendiri siap untuk menjadi pemimpin dalam produksi tersebut. Setelah itu sutradara menyampaikan konsep dan gagasan keproduksian untuk dapat diolah dan dikembangkan berdasarkan sudut pandang keproduksian.

Sutradara selain sebagai pemimpin dalam pementasan, ia juga akan membantu pimpinan produksi yang telah dipercaya untuk mengendalikan keproduksian. Sebelum sutradara menentukan proses latihan, seluruh rumah tangga keproduksian melakukan rapat untuk menentukan siapa-siapa saja yang terlibat dalam proses pementasan. Di bawah penanganan seorang pimpinan produksi, segala tugas yang akan dilaksanakan harus diberikan kepada semua pengurus untuk mulai melakukan tugasnya. Misalnya, pengurusan perijinan tempat, alat musik dan lain sebagainya. Sutradara akan memantau setiap kerja pimpinan produksi dan begitu juga seorang pimpinan produksi terhadap orang-orang yang telah diberikan tugasnya.

\section{Stage Manager, Scenografer, Penata Rias, dan Penata Cahaya}

Pemilihan seluruh tim artistik dipilih berdasarkan pengalaman dalam bidang artistik yang dikehendaki sutradara. Setelah terpilih, seluruh tim artistik hendaknya saling menjaga keakraban antar personal agar tercapainya sebuah tim yang kompak dan mewujudkan sebuah pementasan yang diharapkan.

\section{Proses Pelatihan}

Secara keseluruhan dialog dalam naskah Peterakna, Episode Peri Bunian karya G.P Ade Dharmawi menggunakan bahasa Melayu meskipun tidak seluruhnya disampaikan dengan bahasa Melayu tetapi dialek yang melekat pada dialog haruslah dengan logat melayu. Hal ini sutradara harus memberikan pembelajaran lebih terhadap semua pemain karena latar belakang pemain bukanlah dari kalangan orang melayu. Hal pertama yang harus dilakukan adalah melakukan proses membaca (reading) yang dilakukan secara

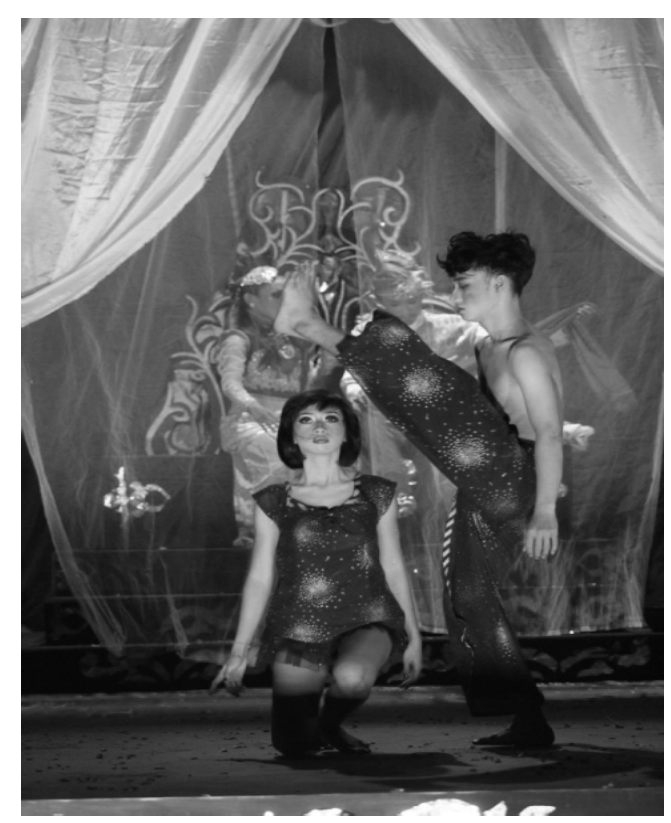

Percintaan Sultan dengan Cik Apong digambarkan melalui tarian (Foto: Sigit Setya)

berulang. Selain itu, pemain diakrabkan dengan logat melayu dengan cara membiasakan untuk berbicara dengan bahasa melayu, memperkaya pendengaran terhadap dialog-dialog yang menggunakan bahasa dan logat melayu guna tercapainya dialog yang sesuai dengan keinginan sutradara.

Tahapan selanjutnya adalah pemain mulai mengenal karakter tokoh yang akan diperankan. Melalui latihan membaca (reading) yang dilakukan secara terus-menerus, pemain dituntut untuk dapat mengenali tokoh yang akan dimainkan serta pemahaman bahasa melayu serta logat melayu. Selain itu, memberikan beberapa contoh rekaman yang menggunakan logat Melayu adalah hal yang dilakukan untuk menambah wawasan mengenai pengenalan dialog terhadap pemain.

Aktor yang baik adalah mampu memberikan ciri khas terhadap peran tokoh yang akan diperankan. Sutradara mengharapkan kepada setiap pemain untuk tidak menghilangkan ciri khas dari pemain tersebut guna untuk memberikan warna pada permainan akting mereka. Tugas dasar seorang aktor adalah keharusan aktor meniru tokoh yang diciptakannya (Yudiaryani, 2000:372). Dalam naskah Peterakna, Episode Peri Bunian karya G.P Ade Dharmawi terdapat beberapa tokoh diantaranya sebagai raja, putri, abdi kerajaan dan lain sebagainya. Hendaknya para pemain mampu mencipta kembali setiap tokoh yang akan dimainkan. 
Setelah keseluruhan tahap perencanaan dan proses kreatif dilakukan, sampailah pada tahap akhir dari perjalanan panjang selama proses yakni pementasan. Melalui gladi bersih, para pendukung proses Peterakna, Episode Peri Bunian karya G.P Ade Dharmawi telah mendapatkan gambaran menuju pementasan. Segala kekurangan ataupun kendala yang dihadapi menjadi cerminan pada gladi bersih sebelumnya untuk menuju ke pementasan. Akhirnya lengkap sudah proses perjalanan sutradara bersama para pendukung artistik dan produksi untuk mewujudkan naskah Peterakna, Episode Peri Bunian karya G.P Ade Dharmawi terhadap masyarakat di kalangan yang bukan Orang Melayu.

\section{Penutup}

Keberadaan Teater Bangsawan sebagai salah satu teater tradisional Melayu pada masa ini sedang menuju kepunahan karena adanya indikasi sulitnya untuk dapat menyaksikan bentuk pementasan Teater Bangsawan secara utuh dan lengkap. Melihat kondisi seperti ini sutradara ingin menimba kembali melalui pementasan Teater Bangsawan di atas panggung teater untuk mewujudkan cita-citanya sebagai sutradara berciri khas tradisi.

Peristiwa yang ditampilkan dalam naskah Peterakna, Episode Peri Bunian karya G.P Ade Dharmawi merupakan kejadian seharihari manusia yang biasa dialami yakni soal percintaan, dalam hal ini terjadi di kalangan Istana yang dialami oleh tokoh Sultan. Ambisi seseorang terhadap nafsu yang mengakibatkan hal yang tidak pantaspun dilakukan, unsur politik yang tergambar dalam imajinasi Sultan demi mewujudkan keinginannya memiliki seorang putra penerus kerajaan.

Proses panjang yang dilakukan sutradara bersama seluruh pendukung artistik dan segenap crew lainnya tidaklah semata-mata berjalan dengan mulus. Banyak konflik dan permasalahan yang terjadi saat proses latihan berbulan-bulan. Hal ini tidak mematahkan semangat sutradara dan pendukung proses untuk tetap berkarya demi terciptanya sebuah pementasan yang baik. Menjadi sebuah pertanyaan besar di awal sutradara tentang bagaimana konsep pementasan dengan mengambil idiom Teater Bangsawan. Namun pertanyaan terjawab saat proses sedang dilalui tanpa adanya pemaksaan, tetapi sebuah bentuk proses yang dilakukan dengan tenang dan mengalir.

Penciptaan naskah Peterakna, Episode Peri Bunian karya G.P Ade Dharmawi memiliki tantangan tersendiri karena kehadiran pemainpemain yang bukan dari kalangan Orang Melayu. Butuh pelatihan khusus di luar proses untuk mewujudkan dialog yang sesuai dengan keinginan sutradara. Selain itu pemilihan Episode Peri Bunian juga merupakan tantangan karena episode ini kerap dipentaskan oleh beberapa orang termasuk penulis naskah. Bagaimana mewujudkan pementasan kali ini dengan nuansa yag berbeda dan menjadi pementasan yang apik serta sampai ke telinga penonton yang merupakan bukan dari kalangan Orang Melayu. Terlepas dari kemiripan bentuk dan gaya, sutradara telah berusaha menciptakan pementasan dengan berbagai kemungkinan kebaruan. Namun pada hakikatnya pasti ada kekurangan-kekurangan dalam mencipta karya.

\section{Kepustakaan}

Akwan. C. 1984. Beberapa Aspek Teater Tradisional di daerah Kebudayaan Biak-Numfor. Jakarta: BPK Gunung Mulia.

Dharmawi, Ade. 2005. Teater Bangsawan Melayu Riau. Pekanbaru: Lembaga Seni Budaya Melayu Sultan Teater Riau/LSBM-STR.

Harymawan. 2001. Dramaturgi. Bandung: Rosda Karya.

Bandem, I Made dan Sal Murgiyanto. 1996. Teater Daerah Indonesia. Yogyakarta: Kanisius.

Kartodirdjo,Sartono.1987.KebudayaanPembangunan dalam Perspektif Sejarah.Yogyakarta: Gadjah Mada University Press.

Masran, Hermansyah. 2000. "Teater Tradisioanl Mamanda di Tembilahan Inderagiri Hilir Riau Indonesia" [Tesis] Akademi Pengkajian Melayu, University Malaya.

Yudiaryani. 2000. Panggung Teater Dunia Perkembangan dan Perubahan Konvensi. Yogyakarta: Pustaka Gondho Suli. 